\title{
SPOSOBY UKAZANIA INNYCH NARODOWOŚCI - SĄSIADÓW, PRZEDSTAWICIELI MNIEJSZOŚCI WE WSPÓŁCZESNEJ KINEMATOGRAFII WĘGIERSKIEJ
}

\author{
Grzegorz BubaK ${ }^{1}$ \\ (Uniwersytet Jagielloński, Kraków)
}

Słowa kluczowe: kinematografia węgierska, obcy, stereotypy

Key words: Hungarian cinematography, foreigner, stereotypes

\begin{abstract}
Abstrakt: Grzegorz Bubak, SPOSOBY UKAZANIA INNYCH NARODOWOŚCI - SĄSIADÓW, PRZEDSTAWICIELI MNIEJSZOŚCI WE WSPÓŁCZESNEJ KINEMATOGRAFII WĘGIERSKIEJ. „PORÓWNANIA” 20, 2017. T. XX. S. 77-86. ISSN 1733-165X. Kinematografia węgierska poza nielicznymi wyjątkami nie wykorzystała swojej szansy, aby w pełni ukazać interesujący, pozbawiony mankamentów obraz obcego, Innego. We wciąż realizowanych filmach twórcom niezwykle trudno jest wyjść poza utrwalone bolesną historią uprzedzenia, stereotypy. Dotyczy to zarówno sąsiadów Węgrów, z którymi nawet obecnie nie udaje się stworzyć poprawnych relacji, jak i przedstawicieli licznych mniejszości narodowych zamieszkujących kraj. W tekście autor dokonuje przeglądu i charakterystyki wizerunków obcych, które można odnaleźć we współczesnej kinematografii węgierskiej, oraz przedstawia problemy towarzyszące stworzeniu spójnego opisu przedstawicieli innych narodowości.
\end{abstract}

Abstract: Grzegorz Bubak, SOME WAYS TO PRESENT OTHER NATIONALITIES - NEIGHBOURS, REPRESENTATIVES OF MINORITIES IN CONTEMPORARY HUNGARIAN CINEMATOGRAPHY. "PORÓWNANIA" 20, 2017. Vol. XX. P. 77-86. ISSN 1733-165X. Hungarian cinema, with only a few exceptions, did not use its chance to offer a full and interesting picture of the Foreigner or the Other that would be devoid of shortcomings. In current movies filmmakers find it very difficult to go beyond established and painful history of prejudices and stereotypes. This applies both to citizens of countries neighbouring with Hungary with which even now it fails to create a correct relationship, and to representatives of numerous national minorities living in the country. The author reviews the images and characteristics of the foreigner which can be found in the contemporary Hungarian cinema and presents problems associated with the creation of a cohesive description of representatives of other nationalities.

1 E-mail: grzegorz.bubak@uj.edu.pl 
Kiedy spogląda się na historię Węgier, widać wyraźnie, że miała ona istotny wpływ na relacje z narodowościami, z którymi Węgrom przyszło koegzystować. Korzenie problemów sięgają wspólnego państwa w obrębie monarchii, którym Węgrzy administrowali, usilnie starając się odrzucać żądania praw innych nacji. Koniec I wojny światowej okazał się kluczowy dla dalszych losów kraju. Rozpad monarchii i rozpaczliwa walka o uratowanie państwa to tylko zapowiedź nadchodzących problemów. Wtedy także powstały kosztem węgierskiego terytorium nowe państwa (Czechosłowacja, Jugosławia), powiększono Królestwo Rumunii. Kraje te były wrogo nastawione do Węgier. Konflikty będą determinowały późniejsze relacje narodowościowe. Wpłynie to w sposób znaczący na stosunki sąsiedzkie w kolejnych dekadach. Szczególnie przełom lat trzydziestych i czterdziestych XX wieku jest okresem pogorszenia relacji z Rumunami i Słowakami za sprawą rewizjonistycznej polityki władz węgierskich.

Modyfikacje granic w sposób odgórny, czyli w wyniku arbitraży międzynarodowych, traktatów, układów kończących wojny, skutkowały pozostaniem przedstawicieli wielu innych narodowości w granicach państwa węgierskiego. Podejmowano wprawdzie próby ich deportacji czy wymiany na Węgrów, którzy znaleźli się poza krajem, choć wcześniej całe życie mieszkali w obrębie Korony św. Stefana² Dość szybko jednak zrezygnowano z tego pomysłu w obawie przed nieprzewidzianymi konsekwencjami takich działań.

Szacuje się, że na Węgrzech mieszka ok. 180 tys. obywateli węgierskich narodowości niemieckiej, 35 tys. rumuńskiej, tyle samo słowackiej, są jeszcze Chorwaci, Serbowie. O ich obecności decydowały zwłaszcza ruchy migracyjne, właśnie przesunięcia granic, działania osadnicze. Jednak w przypadku najliczniejszej obecnie mniejszości zamieszkującej Węgry było trochę inaczej - to nie odgórne decyzje, a wielowiekowe procesy historyczne spowodowały, że na Węgrzech mieszka - według różnych szacunków - od 350 tys. do 800 tys. Romów. Pierwsze grupy docierały do Kotliny Naddunajskiej już z końcem XIV wieku.

Biorąc powyższe pod uwagę, w niniejszym tekście chciałbym poruszyć kwestię ukazania relacji narodowościowych, postrzegania Innych, obcych w stosunku do Węgrów na przykładzie twórczości filmowej. Choć najczęściej w centrum zainteresowania są tzw. sprawy domowe, własne podwórko i jest to element charakterystyczny nie tylko dla twórczości filmowej, ale dotyczy również na przykład literatury, o czym pisze Gábor Erőss (Erőss 60), to jednak obok nich pojawią się także obrazy ukazujące przedstawicieli innych nacji, ich relacje z Węgrami. Opisy te $\mathrm{z}$ jednej strony bazują na stereotypach, uprzedzeniach umocowanych $\mathrm{w}$ trudnej przeszłości, $\mathrm{z}$ drugiej natomiast można $\mathrm{w}$ nich dostrzec próby obalenia powszechnie przyjętych sądów, ukazania faktycznego stanu rzeczy.

2 W ramach tych działań przesiedlono ok. 70 tys. Węgrów z terenów Słowacji i tyle samo Słowaków $\mathrm{z}$ terenów Węgier. 
Istotną cezurą w przypadku omawianej problematyki jest okres zmian systemowych końca lat osiemdziesiątych i początku dziewięćdziesiątych. Wcześniej (mowa o okresie komunistycznym) obcy nie do końca byli obcy - przedstawiciele mniejszości, np. Żydzi ${ }^{3}$ i Romowie, choć postrzegani jako inni byli jednak częścią wspólnego krajobrazu społecznego (wspólna historia, dla wielu także wspólny język węgierski), a sąsiedzi w większości należeli do kręgu oficjalnych przyjaciół. Ogólnie unikano problematyki Innych, społeczeństwo miało być homogeniczne, a przede wszystkim zorientowane komunistycznie.

Jeśli jednak pojawiają się ewentualne odniesienia, to ze względu na ograniczenia systemowe obraz nie-Węgrów w filmach węgierskich jest raczej zniekształcony. Charakterystyczne jest to, że opis pojawia się, poza nielicznymi wyjątkami, tylko $\mathrm{w}$ dziełach historycznych. Bezpieczny w okresie komunizmu gatunek (ponieważ nie odnosił się do współczesności, nie budził nadmiernego zainteresowania władz) wykorzystywał, powielał funkcjonujące stereotypy, stosowano uproszczenia. Potwierdzeniem tego spostrzeżenia jest spłycony wizerunek Austrii i Austriaków w wielu filmach dotyczących tego zaboru. Erőss (Erőss 71) nazywa Austriaka „historycznym odwiecznym wrogiem”, którego wizerunek można odnaleźć na przykład w realiach od XVII wieku - Nieposkromieni hajducy (Hajdúk, reż. Ferenc Kardos, 1974), do wieku XIX: Płatki, kwiaty, wieńce (Szirmok, virágok, koszorúk, reż. László Lugossy, 1984). W filmach Zoltána Várkonyiego Synowie magnata (A kőszívü ember fiai, 1964), Zoltán Kárpáthy (Kárpáthy Zoltán, 1966), Wegierski magnat (Egy magyar nábob, 1979), Czarne diamenty (Fekete gyémántokban, 1981) Austriacy są przeważnie czarnymi charakterami, zaborcami. Reprezentują wrogi system tłumiący węgierskie dążenia narodowościowe. Jednak ze względu na odległe czasy są przez to trochę abstrakcyjnym obcym, nie są z pewnością kojarzeni ze współczesnym sąsiadem. Po zmianie systemu ich wizerunek staje się bardziej stonowany, nie pojawiają się odniesienia historyczne, a raczej kuszące Węgrów sąsiedztwo przedstawicieli tzw. Zachodu. Często tworzy się tu iluzję dobrobytu czy szczęścia (Zsötem, reż. András Salamon, 1992).

Podobnie rzecz ma się z obrazem Chorwatów, których dostrzeżemy niemal wyłącznie $\mathrm{w}$ filmach kostiumowych, czasem jako przyjaciól, innym razem neutralnie nastawionych do Węgrów. Wyjątkiem we współczesnym kinie jest film Ibolyi Fekete Chico (2001) o wojnie w Jugosławii, gdzie obok Chorwatów pojawiają się też Serbowie, równie rzadko obecni $w$ fabułach filmów węgierskich. Istotną rolę odrywa tu chęć zrozumienia południowych Słowian, którzy nagle stają do okrutnej, bratobójczej walki. Reżyserka próbuje wyjaśnić powody bezwzględnych działań obu stron, których przedstawiciele jeszcze do niedawna całkiem dobrze razem funkcjonowali.

Ciekawe wnioski nasuwają się po analizie materiału filmowego pod kątem obecności Rumunów w fabułach filmów. Mogłoby się wydawać, że utrwalone uprze-

3 O relacji ze społecznością żydowską piszę w dalszej części tekstu. 
dzenia w stosunku do tej narodowości zaowocują bardzo negatywnym obrazem, powieleniem stereotypu wrogich, niechętnych Węgrom sąsiadów, tymczasem jest zupełnie inaczej. $j^{4}$ Przede wszystkim jednak jest ich w filmach węgierskich niezwykle mało. Nie stanowią dla twórców najwidoczniej źródła inspiracji. Ponadto te nieliczne prezentacje są różnorodne: od bardzo ogólnych, gdzie Rumuni to po prostu sąsiedzi, np.: Wspaniałe wakacje (A bolondos vakáció, reż. Makk Károly, 1967), przez związane z walką o wolność, którą doskonale rozumieją Węgrzy, aż po stereotypowe odniesienia, choć raczej w konwencji satyrycznej. Przykładem jest scena z filmu Znowu świadek (Megint tanú, reż. Péter Bacsó, 1995), w której rumuńscy imigranci ekonomiczni przybywają na Węgry w trumnach spławianych rzeką.

Podobnie kształtuje się kwestia obecności Słowaków w węgierskich realizacjach. Nawarstwione obustronne pretensje uwidoczniły się szczególnie po zmianie systemu, kiedy bez ograniczeń realiów komunistycznego obozu do głosu doszły lokalne nacjonalizmy. Drastycznie pogorszyła się sytuacja mniejszości węgierskiej na Słowacji. Pokłosie tych nastrojów odnajdziemy na przykład w głośnej adaptacji książki Pála Závady Poduszka Jadwigi (Jadviga párnája, reż. Krisztina Deák, 2000), gdzie nietrudno dostrzec napięcia $\mathrm{w}$ obustronnych relacjach. Jest też symptomatyczna, niemal książkowa postać słowackiego nacjonalisty ${ }^{5}$.

Wracając do sytuacji wewnątrz kraju, mniejszość żydowska, jak wspomniałem, do lat dziewięćdziesiątych nie była postrzegana jako obcy element. Zamiast na inność, wskazywano raczej na tożsamość doświadczeń. Sprawcami nieszczęść obu narodów byli w tych dziełach "oni", „tamci”, reprezentanci systemu faszystowskiego: Niemcy i węgierscy naziści.

Świadectwem wspólnoty losu jest między innymi Holocaust, który będzie odgrywał kluczową rolę właśnie po upadku komunizmu, determinuje on w tym okresie relacje węgiersko-żydowskie, co pokazują filmy: Glamour (2000) Frigyesa Gödrösa; Moja młodsza siostra (Az én kis növérem, 1996) Andrása Síposa, Elysium (1986) Eriki Szántó, Ziemia niczyja (Senkiföldje, 1993) Andrása Jelesa, Kropla słońca (A napfény ize, 1998) Istvána Szabó, Moje pierwsze dwieście lat (Első kétszáz évem, 1985) Gyuli Maára i Los utracony (Sorstalanság, 2004) Lajosa Koltaia. W tych filmach to przede wszystkim Żydzi są ofiarami historii. Ukazane w nich zostały dramatyczne

4 Gordon Allport zaproponował bardzo rozsądne, moim zdaniem, objaśnienie mechanizmów towarzyszących powstawaniu stereotypów właśnie: „Myślenie stereotypowe tkwi głęboko w kulturze, historii i pamięci zbiorowej. Nie odzwierciedla jedynie realnych, dawnych lub niedawnych konfliktów, choć nie sposób go od nich całkowicie oddzielić. Wszak stereotypy rodzą się w wyniku napięć i rywalizacji, frustracji i agresji. Stereotypizacja jest „prawem najmniejszego wysiłku” (...). Wyręcza z myślenia o tym, jak naprawdę wygląda świat, mimo że sprowadza go do krzywdzących uproszczeń. Dotyczy to zwłaszcza stereotypów narodowych, które raz sformułowane zdają się odporne na rewizję i modyfikację". (cyt. za:Purchla 1).

5 Węgrzy w przeszłości wielokrotnie używali terminu panslawizm zagrażającego integralności ziem węgierskich i manipulowali nim. Wśród uczestników tego ruchu aktywni mieli być nieprzychylni Węgrom właśnie Słowacy. 
próby przetrwania, uległość, naiwna wiara w sprawiedliwość, w litość oprawców. Pomoc rzadko przychodzi ze strony Węgrów. Ważną zmianą w stosunku do okresu Horthyego, w którym niemal standardem było eksponowanie negatywnych cech tej grupy etnicznej (np. pazerność, żerowanie na nieszczęściu Węgrów), jest zauważalny brak tych elementów.

Erőss zwraca uwagę na jeszcze dwa aspekty widoczne w sposobie przedstawiania Żydów w filmie (Erôss 1973). Jeden z nich to pierwiastek tajemniczości obcych, jak w filmie Diany Groó Cud w Krakowie (Csoda Krakkóban, 2004). Choć to film współczesny, jest mocno zakorzeniony w historii, odnosi się do wielonarodowej Galicji, gdzie obcym tak naprawdę był przybysz, a nie przedstawiciel innej nacji. Wspólna historia ubogaca, jest pozytywna. W filmie młodej węgierskiej reżyserki mieszają się języki, opowieści sprzed wielu lat, wzajemne poznawanie się prowadzi do odnalezienia wspólnego dziedzictwa, bogatej przeszłości, która fascynuje i zachwyca. Doskonałą ilustracją jest spotkanie głównego bohatera z rabinem i duchem babki; każde z nich mówi własnym językiem: rabin po niemiecku, babka po węgiersku, a Piotr po polsku, jednak doskonale się rozumieją, często zresztą używają mowy swoich rozmówców. Okazuje się więc, że odmienność nie jest barierą, ale może stanowić element mozaiki.

Drugim aspektem jest kwestia tożsamości społeczności żydowskiej zasymilowanej po wojnie ze środowiskiem węgierskim. Odnajdywaniu tożsamości ma służyć pielęgnowanie tradycji i zwyczajów. Jako przykład może posłużyć ponownie Cud w Krakowie, Film... (2000) Andrása Surányiego, Skorpion zjada bliźnięta na śniadanie (A skorpió megeszi az ikreket reggelire, 1992) Pétera Gárdosa i Kilka szczęśliwych lat mego ojca (Apám néhány boldog éve, 1977) Sándora Simó oraz Kropla słońca (Szabó 1998). Twórcy przenoszą na ekran uroczystości, które przez dekady były pieczołowicie przekazywane kolejnym pokoleniom, nawet wtedy, kiedy członkom społeczności groziło niebezpieczeństwo.

Szczególne miejsce w kontekście relacji z innymi narodowościami zamieszkującymi kraj zajmują Romowie. Omawiając ich sytuację na Węgrzech, warto zastanowić się nad problemem inkulturacji. Ta najliczniejsza grupa etniczna po Węgrach, żyjąca od wieków w państwie węgierskim, była traktowana jako obcy element spoleczeństwa. Wiąże się to z brakiem kulturowej akomodacji. Romów charakteryzuje bardzo silne poczucie odmienności, pogłębione wyalienowaniem, które uniemożliwia wrastanie w lokalne społeczności. Przedstawiciele romskiej mniejszości na Węgrzech, podobnie jak $\mathrm{w}$ innych europejskich krajach, tylko $\mathrm{w}$ niewielkim stopniu integrują się z resztą społeczeństwa, najczęściej żyją na jego marginesie, co przejawia się na przykład w tym, że romskie dzieci nie chodzą do szkół. Wśród tej społeczności wysoki jest odsetek bezrobotnych i wskaźnik przestępczości, ponieważ przy liczbie ok. 750 tys. Romów mieszkających na Węgrzech prawie $80 \%$ osób pełnoletnich jest bez pracy (HR Portal), co stwarza liczne konflikty, rodzi antagonizmy. Część Węgrów oczekuje niemalże całkowitej asymilacji, inni z kolei chcieliby, aby 
Romowie przynajmniej częściowo włączyli się do życia społecznego w kraju, respektowali ogólnie przyjęte zasady.

W latach sześćdziesiątych twórcy, za zgodą władz państwowych, interesowali się problematyką cygańską. Zgoda była konieczna, ponieważ w systemie komunistycznym społeczność romska wyłamująca się z ustalonego szablonu funkcjonowania obywateli była trudnym problemem do rozwiązania. Starano się zarządzeniami administracyjnymi, restrykcjami dyscyplinować węgierskich Romów - przeważnie $\mathrm{z}$ mizernym skutkiem. Filmowcy natomiast dostrzegali $\mathrm{w}$ tej hermetycznej grupie wielki potencjał artystyczny. Doskonałym przykładem zwrócenia uwagi na mniejszość romską jest dokument Sándora Sáry Cyganie (Cigányok, 1962). Reżyserowi udało się przekroczyć barierę obcości, wcześniej nie do pokonania. Pokazał ich zwyczaje, tradycje, obrzędy, odrzucił utrwalane wciąż stereotypy na przykład o lenistwie, przestępczości. Warto zauważyć, że przed upadkiem komunizmu Romowie $\mathrm{w}$ filmach pojawiali się jako egzemplifikacja problemu społecznego, nieprzystosowania, współcześnie zaś widać, że twórcy zwracają uwagę również na pozytywne aspekty ich funkcjonowania: kulturę, odmienność, czego film Sáry był doskonałym zwiastunem.

Współczesną odpowiedzią na film Sáry jest dzieło, również dokument, Sándora Mohiego Jak sobie Bóg życzy... film Olgi (Ahogy az Isten elrendeli... Olga filmje, 2000), który - także w konwencji czarno-białej - ukazuje bogactwo kultury romskiej. W tym celu ekipa filmowa towarzyszy młodej kobiecie w jej życiu codziennym, od poranka po wieczór. Kamera rejestruje wszystko to, czego doświadcza kobieta, relacje z bliskimi, radości i smutki przedstawicieli tej wyalienowanej społecznoścí.

Przykładem próby pokazania bogactwa duchowego, kulturowego Romów jest film Ildikó Szabó Chacho Rom (2002), co należy z języka romskiego tłumaczyć jako 'prawdziwy Cygan, Rom'. Nie jest to jednak współczesna opowieść, lecz epicki, historyczno-kostiumowy film, który stara się, może w innym świetle, pokazać tę kulturę i obyczaje. Wątkiem wielokrotnie powracającym jest siła miłości, uczucia, które niejednokrotnie komplikuje ludziom życie, wpędzając ich w kłopoty, zmuszając do impulsywnego, nieprzemyślanego działania, do knucia intryg, spisków i dokonywania zbrodni.

Szabó zmierza do tego, by pokazać Romów jako romantyczny naród, kochający wolność i przekazujący swoją ekspresję przede wszystkim w muzyce. Nie jest to zadanie łatwe, czasem trzeba przekroczyć granicę znanych i utrwalonych stereotypów. Ścieżka dźwiękowa zawiera zarówno klasyczne utwory z repertuaru cygańskiego (często mylnie zresztą utożsamiane z ludową muzyką węgierską), jak i fragmenty opracowane specjalnie na potrzeby filmu. Dzieło Szabó jest rzeczywi-

6 Warto również wspomnieć o kolejnej ważnej próbie ukazania problemów Romów w filmie dokumentalnym Kriszty Bódis $\mathrm{Az}$ Isten adóssága z 2002 roku. 
ście sporym wyzwaniem realizacyjnym łączącym elementy bogatej, rozbudowanej wizualności (kolorystyka) z warstwą dźwiękową (muzyka).

Inny obraz o tej tematyce to zrealizowany przez Diánę Groó po kilku latach od debiutu film Vespa (2010), który pozbawiony jest oniryzmu, metafizyki, tajemniczości Cudu w Krakowie. Jego miejsce zajmuje realizm, brutalność i dziecinna naiwność postrzegania świata. O ile w debiucie zderzenie kultur, narodowości było elementem pozytywnym, o tyle teraz relacje węgiersko-romskie mają charakter niemalże destrukcyjny. Vespa reprezentuje gatunek filmu drogi, podróży nie tylko w przestrzeni, ale również mającej charakter pewnego doznania, doświadczenia. Podróż sama w sobie nie jest wprawdzie tą na miarę przemierzania na przykład Ameryki z jednego wybrzeża na drugie. W warunkach węgierskich obejmuje niewielką prowincjonalną miejscowość i stolicę kraju, Budapeszt, choć w przypadku dziecka, będącego głównym bohaterem, jest jednak wielkim wyzwaniem. Motyw prowincji jest charakterystyczny dla pewnego nurtu kinematografii węgierskiej, gdzie dychotomia Budapesztu i reszty kraju jest wyraźna. W filmie Groó opozycje są bardzo widoczne: prowincja jest spokojna, cicha, przewidywalna, ale równocześnie biedna i zacofana. Metropolia natomiast jest głośna, kolorowa i niebezpieczna, jednak dzięki temu fascynuje, intryguje.

Lali, mały chłopiec z romskiej wioski, podobnie jak jego rówieśnicy nie przepada za szkołą, razem z kolegami wagaruje, gra w karty. Pewnego dnia wygrywa tabliczkę czekolady, która - jak się później okazało - zawierała zwycięski kupon $\mathrm{w}$ atrakcyjnej promocji. Lali stanie się posiadaczem pięknego, czerwonego skutera, jeśli tylko uda się do stolicy i osobiście odbierze nagrodę. Dla chłopca, który nie posiada żadnej własnej zabawki, wygrana jest czymś całkowicie abstrakcyjnym, wpatruje się więc w opakowanie czekolady, na którym widnieje zdjęcie tytułowej vespy. Dochodzi jednak do wniosku, że skoro los dał mu taką szansę, musi ją wykorzystać, i postanawia wyruszyć do miasta. Dodatkową motywacją jest poszukiwanie ojca, który ponoć właśnie w Budapeszcie znalazł pracę, porzuciwszy rodzinę.

Jako jedna z niewielu współczesnych reżyserów węgierskich Groó postanowiła w swoim filmie zbadać skomplikowane relacje, zrewidować utrwalone stereotypy ${ }^{7}$. Stosuje tradycyjną narrację, chętnie jednak powraca do swoich dokumentalnych korzeni, które wyznaczyły w pewien sposób jej filmową drogę. Krytyka społecznych relacji jest jednak bardzo widoczna. Czy jest tu kwestia tożsamości, jej poszukiwania, trudno orzec jednoznacznie, być może dla młodego człowieka będzie ona w jakiś sposób budowana tą podróżą. Istotną rolę odgrywa z pewnością Budapeszt jako ogromna przestrzeń, gdzie współegzystują kultury, bo choć młody Rom czuje się obco, to jednak można sobie wyobrazić, że znalazłby tu swoje miejsce.

7 Temat relacji węgiersko-romskich podejmuje także na przykład Bence Gyöngyössy w filmie Romani kris - Cigánytörvény (1997), choć stosuje zupełnie inną poetykę. 
Groó wskazuje na problemy społeczne ale z silnym akcentem wątku etnicznego determinującym pewne postawy. Stereotypy, uprzedzenia niemal automatycznie spychają przedstawicieli danej społeczności na margines, tym samym utwierdzając większość w słuszności swoich przekonań. Przykładem może byś scena, w której chłopiec dociera wreszcie do siedziby organizatora promocji i próbuje upomnieć się o nagrodę. Efektem jego działania jest jedynie narastająca irytacja i podejrzliwość pracownika firmy, widzącego w Lalim potencjalnego oszusta i złodzieja. Nie mieści mu się w głowie, że młody Rom mógł wejść w posiadanie zwycięskiego kuponu w uczciwy sposób.

Sporo miejsca poświęciłem kwestii romskiej, ale uważam, że w sposób szczególny ukazuje ona stosunek Węgrów do innych narodowości. Przecież podobny obraz świata prezentowany jest w Zagubionych (Veszettek, 2015, reż. Krisztina Goda) ${ }^{8}$, choć fabuła tego filmu może zaskakiwać. Pozornie jest to współczesna wersja klasycznego westernu. Małe miasteczko, gdzieś na węgierskiej prowincji, popada w marazm, grupy wyrostków terroryzują miejscową ludność, szczególną niechęć, wrogość przejawiają wobec społeczności romskiej egzystującej w swoim getcie. Nawet nowy ",szeryf" szybko sam ulega sile posiadanej władzy.

Twórcy węgierscy w dalszym ciągu dość niechętnie sięgają po motyw obcego, nie do końca wiedzą, jak uporać się z mocno zakorzenionymi w świadomości rodaków stereotypami, choć pojawiające się próby świadczą, że jest to możliwe. Filmy Szabó, Groó, Sáry dowodzą, że kinematografia węgierska jest w stanie stworzyć kompletny, obiektywny obraz obcego, Innego, obraz, który jest w dodatku interesujący. Otwarte pozostaje pytanie, czy pojawią się wkrótce kolejne realizacje o podobnej tematyce. Aktualna sytuacja polityczno-społeczna Węgier pozwala przypuszczać, że tak będzie; przecież Węgrzy, podobnie jak pozostała część Europy, stanęły w obliczu fali uchodźców. Ta konfrontacja prędzej czy później zaowocuje spostrzeżeniami węgierskich filmowców.

\section{BIBLIOGRAFIA}

Bilewicz, Michał. „Kiedy kontakt osłabia uprzedzenia? Kategoryzacje społeczne i temporalne jako warunki skuteczności kontaktu międzygrupowego". Psychologia Społeczna 2 (2006). S. 63-74.

Erőss, Gábor. „Az idegen, filmnyelven szólva Külföldiek és kisebbségek a magyar filmekben” 2005.

Web. 15.12.2016. <http://www.efolyoirat.uz.ua/00000/00036/00060/pdf/077-130.pdf>

HR Portal - Web. <80 százalékos a cigányság körében a munkanélküliség, http://www.hrportal.hu/c/80szazalekos-a-ciganysag-koreben-a-munkanelkuliseg-20121121.html>

Kochanowski, Jerzy. Wegry. Od ugody do ugody 1867-1990. Warszawa: Wydawnictwo Trio, 1997.

Muhi, Klára. „Roma zsaru, magyar bún”. Filmvilág 10 (2008). S. 52-53.

8 W Polsce pokazywany był jej film 1956. Dzieci chwały, (Szabadság, szerelem, 2006). 
Purchla, Jerzy. „Narody i stereotypy”. Herito 15 (2014). S. 1-4.

Raczek, Tomasz. „Przekwitanie nadziei”. Kino 9 (1985). S. 46-47.

Szemző, Ildikó. Kisebbségek A filmmúvészetben. Web. 15.12.2016. <http://nemzetisegek.hu/repertorium/2010/03/belivek_21-22.pdf> 